\title{
Penerapan Rencana Pelaksanaan Pembelajaran dalam Pembelajaran Sosiologi (Studi Kasus SMAN 3 Painan dan SMAN 2 Bayang)
}

\author{
Yorisa Yora Marwa ${ }^{1}$, Reno Fernandes ${ }^{2}$ \\ ${ }^{1,2}$ Universitas Negeri Padang \\ Email: yorimarwa47@gmail.com, renofernandes@fis.unp.ac.id.
}

\begin{abstract}
Abstrak
Penelitian ini bertujuan untuk mengetahui bagaimana penerapan rencana pelaksanaan pembelajaran dan kendala dalam penerapan rencana pelaksanaan pembelajaran di SMAN 3 Painan dan SMAN 2 Bayang. Dalam menganalisis penelitian ini, peneliti menggunakan teori Talcott Parson yaitu AGIL. Penelitian ini menggunakan pendekatan kualitatif deskriptif dan pemilihan informan purposive sampling. Data dikumpulkan dengan cara observasi, wawancaradan dokumentasi dengan teknik analisis data dari Miles dan Huberman. Penelitian ini menunjukkan berbagai permasalahan dalam penerapan dan kendala rencana pelaksanaan pembelajaran yaitu, (1). Kesiapan guru; (2).Karakteristik peserta didik; (3). Kendala guru; (4).Upaya kepala sekolah dan; (5).Hubungan peserta didik, guru dan kepala sekolah. Penerapan rencana pelaksanaan pembelajaran berdasarkan kurikulum 2013 pada mata pembelajaran sosiologi sudah di implementasikan tapi belum optimal.
\end{abstract}

Kata Kunci: Penerapan, RPP, Guru

\section{Abstract}

This study aims to determine how the implementation of the learning plan and the constraints in implementing the learning plan in SMAN 3 Painan and SMAN 2 Bayang. In analyzing this study, researchers used Talcott Parson's theory, namely AGIL. This study uses a descriptive qualitative approach and the selection of purposive sampling informants. Data were collected by means of observation, interviews and documentation with data analysis techniques from Miles and Huberman. This study shows various problems in the implementation and constraints of the learning implementation plan namely, (1). Teacher readiness; (2). Characteristics of students; (3). Teacher constraints; (4). Principal's efforts and; (5). Relationship of students, teachers and school principals. The implementation of the learning plan based on the 2013 curriculum in sociology subjects has been implemented but not yet optimal.

Keywords: Implementation, RPP, Teacher

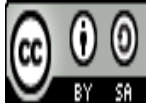

Received: August 5, 2019 Revised: August 8, 2019 Available Online: September 30, 2019 


\section{Pendahuluan}

Pesatnya perkembangan ilmu pengetahuan dan teknologi saat ini telah membawa pengaruh yang besar pula pada segala bidang kehidupan manusia, salah satunya adalah bidang pendidikan. Pendidikan merupakan salah satu faktor yang dapat menentukan perkembangan suatu Negara. (Sylvia, 2012) Peningkatan mutu pendidikan merupakan salah satu strategi pembangunan pendidikan di Indonesia. Upaya tersebut memiliki peranan strategis dalam kerangka pembangunan bangsa Indonesia secara keseluruhan, menyangkut upaya penyiapan sumber daya manusia sebagai pelaksanaan pembangunan dimasa yang akan datang. Peraturan Pemerintahan no 32 tahun 2013 mengenai standar pendidikan Indonesia memuat kompetensi lulusan, standar isi, proses, standar pendidik dan tenaga kependidikan, sarana dan prasarana, pengelolaan, pembiayaan pendidikan, semua menjadi pembentukkan kompetensi siswa (Mulyasa, 2008). (1, Setyawanto, 2. H.S, \& Basuki, 2017).

Pendidikan Indonesia telah mengalami perubahan-perubahan kebijakan pendidikan. Perubahan yang dilakukan oleh pemerintah tersebut diharapkan dapat memajukan sumber daya manusia di Indonesia sehingga mendorong kemajuan bangsa. Permendikbud tahun 2013 menjelaskan perangkat pembelajaran di buat dalam bentuk silabus dan RPP berpedoman pada standar isi. Rencana Pelaksanaan Pembelajaran (RPP) merupakan pedoman dalam melaksanakan pembelajaran atau tatacara dalam pembelajaran untuk mencapai kompetensi dasar yang ditetapkan dalam standar isi dan dalam silabus. Perencanaan langkah-langkah pembelajaran telah mencakup kegiatan pendahuluan, kegiatan inti, dan kegiatan penutup. Kegiatan pendahuluan telah mencakup aspek menyampaian tujuan pembelajaran/menyampaikan apersepsi awal tentang materi yang akan dipelajari, tetapi belum mencakup aspek 4 mengaitkan kehidupan nyata dan pengetahuan terdahulu dengan $\mathrm{KD}$, dan guru belum mendemonstrasikan sesuatu berkaitan dengan KD. Salah satu faktor yang mempengaruhi keberhasilan pembelajaran yaitu proses pelaksanaannya.jika perencanaan pembelajaran dibuat dengan baik maka pelaksanaan pembelajaran akan berjalan dengan baik. Kegiatan pembelajaran salah satu bentuk dari penerapan RPP di dalam kelas. Perencanaan menggambarkan apa yang harus kita lakukan dari awal pembelajaran sampai akhir pembelajaran. (Nadzir, n.d.)

Penyusunan pembelajaran harus dilakukan oleh guru pada saat akan melaksanakan tugasnya artinya guru tidak akan bisa mengajar karena tidak memiliki persiapan yang matang dalam perencaan pembelajaran (Nadzir, n.d.). Perencanaan dan pelaksanaan pembelajaran yang dilakukan tidak sesuai dengan pedoman maka tidak akan mencapai keberhasilan dan membuat kurang menariknya pembelajaran sehingga peserta didik merasa bosan, tidak membuat peserta didik untuk aktif dan kreatif, sehingga apa yang menjadi tujuan tidak tercapai. (Hakim, 2010). Pembelajaran yang baik dan akan mencapai tujuan harus disertai perencanaan pengajaran sebagai pedoman dalam mengajar (Mulflikh, 2017). Keberhasilan implementasi tergantung oleh kemampuan yang dimiliki seorangguru, karena guru merupakan perancang, pelaksana sekaligus pengembang kurikulum di kelasnya.

Peran penting dalam memandu guru melaksanakan tugasnya sebagai pendidik adalah Perencanaan yang matang. Oleh karena itu, seorang pendidik harus memiliki perencanaan karena itu fungsi pedagogi untuk meningkatkan kualitas pelaksanaan pembelajaran dan untuk memotivasi pendidik (s. suherman, n.d.). Sebagaimana yang kita ketahui perangkat pelaksanaan pembelajaran bertujuan mengevaluasi dan merefleksi peserta didik dan merupakan kewajiban guru membuat rencana pelaksanaan sebelum pembelajaran. Dengan berpedoman kepada perencanaan yang baik, guru akan memiliki persiapan untuk melaksanakan proses pembelajaran. Kegiatan pembelajaran yang terencana sesuai pedoman akan berlangsung secara efektif dan mencapai suatu tujuan.

Dari hasil observasi yang telah dilakukan peneliti di SMAN 2 Bayang dan SMAN 3 Painan kurikulum 2013 telah di implementasikan begitu pun dengan perencanaan yang dibuat

Jurnal Sikola: Jurnal Kajian Pendidikan dan Pembelajaran Vol. 1, No. 1, Th. 2019 
Yorisa Yora Marwa, Reno Fernandes Penerapan RPP dalam Pembelajaran Sosiologi (Studi kasus SMAN 3 Painan dan SMAN 2 Bayang) oleh pendidik, akan tetapi belum dilaksanakan dengan optimal dan dalam penerapan pembelajarannya masih ditemukan kesulitan-kesulitan dari membuat perencanaan pembelajaran sampai dalam pelaksanaan pembelajarannya. Dalam hal ini peniliti ingin melihat bagaimana penerapan serta kendala penerapan RPP dalam mata pelajaran sosiologi berdasarkan kurikulum 2013 di SMAN 2 Bayang dan SMAN 3 Painan.

Kurikulum 2013 menjanjikan lahirnya generasi penerus bangsa yang produktif, kreatif, inovatif, dan berkarakter. Untuk mewujudkan hal tersebut, dalam implementasi kurikulum, guru dituntut secara profesional merancang pembelajaran efektif dan bermakna, mengorganisasikan pembelajaran, memeilih proses pembelajaran yang tepat, menentukan prosedur pembelajaran dan pembentukan kompetensi secara efektif, serta menetapkan kriteria keberhasilan. Daya serap atau daya tengkap peserta didik terhadap pembelajaran yang telah di ajarkan merupakan indiator keberhasilan belajar, dan apa yang di pelajari diterapkan dengan perbuatan atau tingkah laku yang ada dalam tujuan pembelajaran itu juga indikator keberhasilan belajar peserta didik baik secara individual maupun kelompok. (Ibrahim, 2016) perencanaan, pelaksanaan, dan penilaian merupakan tiga fungsi pembelajaran sebagai inti dari implementasi kurikulum.

Guru profesional dalam mengajar adalah guru yang berpedoman kepada rencana pelaksanaan pembelajaran yang baik dan benar. Berdasarkan latar belakang diatas, Rancangan Pelaksanaan Pembelajaran seorang guru diharapkan dapat diterapkan terstruktur dan terprogram. Guru harus mempunyai kemampuan dalam mengembangkan RPP sehingga dan memahami penyusunan RPP dengan baik karena itu berpengaruh dengan hasil pembelajaran. Hal ini juga sesuai dengan pendapat (Prambanan, Irenewaty, Hum, \& Sejarah, 2006) kurangnya pemahaman terhadap adanya otonomi guru dalam mengembangkan RPP, kurangnya pemahaman terhadap Permendikbud nomor 65 tahun 2013 terkait penyusunan RPP, terbatasnya referensi untuk pengembangan RPP, dan adanya kebingungan dengan model RPP yang beragam. Peneliti tertarik meneliti ini karena ingin melihat bagaimana penerapan rencana pelaksanaan pembelajaran dan apa kendala guru dalam menerapkan rencana pelaksanaan pembelajaran di SMAN 3 Painan yang dikenal sebagai SMA unggul di Kabupaten Pesisir Selatan dan sering memenangkan olimpiade sosiologi setiap tahun di Universitas Negeri Padang dengan SMAN 2 Bayang yang dibilang belum seunggul SMAN 3 Painan.

\section{Metode Penelitian}

Dalam penelitian ini peniliti menggunakan pendekatan deskriptif kualitatif, yaitu penelitian yang hasilnya berupa gambaran data melalui pengumpulan fakta-fakta dan wawancara yang dilakukan dengan pemilihan infroman oleh penliti dengan instrumen dari peneliti sendiri(j.1, 2004). Memahami fenomena yang terjadi oleh informan yang akan di teliti dengan cara menggambarkan dalam bentuk kata-kata dan bahasa itu maksud dari penelitian kualitatif ini, pada suatu objek khusus yang alamiah dengan memanfaatkan berbagai metode ilmiah (j.1, 2004) Tipe penelitian ini bersifat memberikan gambaran yaitu di SMAN 3 Painan dan SMAN 2 Bayang. Penelitian yang dilakukan peniliti ini bersifat deskriptif karena menggambaran penerapan dan kendala rencana pelaksanaan pembelajaran yang terjadi di SMAN 3 Painan dan SMAN 2 Bayang. Peneliti memilih Deskriptif karena tujuan dari penelitian ini memberikan gambaran mengenai proses penerapan rencana pelaksanaan pembelajaran berdasarkan kurikulum 2013.

Informan di pilih oleh peneliti sendiri dengan menyesuaikan infroman dengan apa yang akan peneliti teliti. Sehingga mendapatkan informasi dari berbagai inforan dan berbagai sumber dan dijadikan dasar dari rancangan dan teori yang akan di buat, maka dari itu pemilihan informan dilakukan secara purposive sampling dimana informan ditentukan oleh peneliti dengan jumlah informan sebanyak 6 orang. Peneliti sangat memperhatikan pemilihan informan secara purposive yang dijadikan dasar dalam penentuan objek yang mungkin di gunakan (Basrowi \& Suwandi, 2008). Dalam penelitian ini subjek meliputi peserta didik, guru sosiologi dan kepala sekolah di SMAN 3 Painan dan SMAN 2 Bayang.

Jurnal Sikola: Jurnal Kajian Pendidikan dan Pembelajaran Vol. 1, No. 1, Th. 2019 
Teknik observasi dilakukan dengan cara mengamati secara langsung kegiatan pembelajaran yang dilakukan oleh guru dalam melakukan proses pembelajaran di SMAN 3 Painan dan SMAN 2 Bayang. Observasi dilakukan dengan melihat langsung ke SMAN 3 Painan dan SMAN 2 Bayang dan melihat kegiatan guru dalam melaksanakan proses pembelajaran aktivitas beribadah serta mengamati cara guru dalam menyampaikan pembelajaran. Observasi dilakukan dengan non partisipan, disini peneliti tidak terlibat langsung dengan apa yang akan diteliti yaitu penerapan rencana pelaksanaan pembelajaran dalam pembelajaran sosiologi di SMAN 3 Painan dan SMAN 2 Bayang dimana peneliti memberikan beberapa pertanyaan kepada peserta didik, guru sosiologi dan kepala sekolah yang memungkinkan peserta didik, guru sosiologi dan kepala sekolah bisa bebas memberikan pendapat(W. John, 2010).

Setelah melakukan observasi peneliti melakukan wawancara dengan subjek penelitian peserta didik, guru sosiologi dan kepala sekolah. Dengan wawancara dengan informan, peneliti memdapatkan informasi yang dilakukan dengan cara dialog (Arikunto, 2006). Dengan terbuka wawancara dilakukan dengan tujuan mendapatkan data yang jelas dan dilakukan berkali-kali sesuai dengan keperluan. Supaya data yang peneliti peroleh dalam penelitian akurat, jelas dan sah maka dilakukan dengan teknik trigulasi data dengan cara membandingkan data hasil wawancara, observasi, dan dokumentasi. Apabila ke tiga data dikumpulkan dengan teknik yang berbeda dan menghasilkan data yang berbeda-beda, maka peniliti melakukan wawancara lebih lanjut kepada informan yang bersangkutan untuk memperoleh data yang dianggap benar(sugiyono, 2005). Menganalisis data menggunakan teknik analisis data dari Miles dan Huberman.

\section{Hasil dan Pembahasan}

Penerapan Rencana Pelaksanaan Pembelajaran dalam Pembelajaran Sosiologi (Studi Kasus di SMAN 3 Painan dan SMA 2 Bayang). Peneliti melihat guru sosiologi dalam menerapkan Rencana Pelaksanaan Pembelajaran baik di SMAN 3 Painan dan SMAN 2 Bayang dari kesehariannya selama di sekolah dan menjalankan perannya sebagai guru. Tidak hanya dilihat dari rutinitasnya mengajar di sekolah, tapi dilihat dari semua kegiatan yang dilakukan oleh guru sosiologi. Adapun komponen yang peneliti amati meliputi; 1) adaptasi , 2) pencapaian tujuan, 3) integrasi (penyatuan), 4) latency (pemeliharaan pola). Berikut adalah gambaran penerapan rencana pelaksanaan pembelajaran dalam pembelajaran sosiologi adalah:

a. Kesiapan guru dalam penerapan Rencana Pelaksanaan Pembelajaran berbasis kurikulum 2013. Dan dilihat bahwa guru harus mempunyai kesiapan dalam menerima perubahan dalam RPP dan harus siap menerapkan pembelajaran sesuai RPP berdasarkan kurikulum 2013 karena sebagai guru yang profesional harus bisa melaksanakan tugasnya dengan ketentuan dan peraturan yang telah ada. (Abrory \& Kartowagiran, 2014) Dalam melaksanakan proses pembelajaran pendidik perlu menciptakan cara yang tepat agar terlihat menarik, dan tidak membosankan, sehingga siswa mempunyai motivasi yang tinggi untuk belajar.

b. Dengan karakter peserta didik yang berbeda-beda guru harus bisa mencapai tujuan pembelajaran yang di rencanakan, dan dilihat hasilnya guru sosiologi di SMAN 2 Bayang dan SMAN 3 Painan bisa mengatasi itu dan karakter peserta didik mendukung dan memotivasi pelaksanaan pembelajaran sesuai RPP yang telah di buat berdasarkan kurikulum 2013.

c. Kendala guru dalam penerapan RPP berdasarkan kurikulum 2013. (Terry Irenewaty, 2017) Ada beberapa kesulitan-kesulitan yang banyak dialami guru dalam pembelajaran adalah: (1) kesulitan dalam mengembangkan Rencana Pelaksanaan Pembelajaran, (2) menyiapkan materi pembelajaran, (3) menggunakan media yang menarik, (4) membuat siswa fokus (5) menerapkan variasi metode pembelajaran, (6) memberikan respon, (7) memberikan rangsangan motivasi, (8) mengevaluasi pembelajaran secara komprehensif. Penerapan RPP

Jurnal Sikola: Jurnal Kajian Pendidikan dan Pembelajaran Vol. 1, No. 1, Th. 2019 
Yorisa Yora Marwa, Reno Fernandes Penerapan RPP dalam Pembelajaran Sosiologi (Studi kasus SMAN 3 Painan dan SMAN 2 Bayang) kurikulum 2013 sudah dilaksanakan namun belum optimal karena kendala sarana dan prasarana di SMAN 2 Bayang dan kendala waktu yang terbatas di SMAN 3 Painan sehingga akan menghambat pencapaian tujuan pembelajaran, walaupun begitu karakter peserta didik sangat mendukung dalam proses pembelajaran sehingga pmebelajaran bisa disampaikan dengan jelas dan peserta didik bisa paham tentang pembelajaran yang diajarkan. (Ernawati, n.d.) dalam membuat RPP guru sangat mengalami kesulitan dari penggunaan kata-kata taksonomi Bloom, kemudian beberapa guru sulit untuk menerapkan kurikulum 2013.

d. Upaya kepala sekolah dalam meningkatkan kinerja guru dalam menerapkan RPP berdasarkan Kurikulum 2013. Kepala sekolah sangat berperan penting di dalam sekolah untuk meningkatkan kinerja guru dalam menerapkan RPP berdasarkan kurikulum 2013, kepala sekolah memberikan reword tersendiri dan penyuluhan atau worhsop mengenai pembuatan RPP kepada guru sosiologi dan guru lainnya.

e. Hubungan antara peserta didik, guru dan kepala sekolah. Di SMAN 2 Bayang dan SMAN 3 Painan dilihat dari hubungan peserta didik dengan guru, serta kepala sekolah itu sangat baik. Jika hubungan didalam satu sistem baik maka akan semakin tinggi tingkat kerja sama yang dilakukan untuk mencapai suatu tujuan yang di harapkan.

Dari observasi yang peneliti lakukan di SMAN 3 Painan dan SMAN 2 Painan, guru dan kepala sekolah telah mengimplementasikan renacan pelaksanaan pembelajaran tapi belum optimal karena ada beberapa kendala yang dapat menghambat proses pembelajaran tapi walaupun begitu karakter peserta didik sangat mendukung dalam proses belajar mengajar karena keingin tahuan akan sesuatu peserta didik itu tinggi, jadi walaupun ada pengehambat dalam pembelajaran peserta didik tetap semangat. Kendala yang menjadi penghambat proses pembelajaran yaitu masalah sarana dan prasarana di SMAN 2 Bayang dan keterbatasan waktu dalam pembelajaran di SMAN 3 Painan. Talcott Parson terkenal dengan imperatif fungsional bagi sistem "tindakan " yaitu Skema AGIL suatu fungsi adalah kumpulan kegiatan yang ditujukan ke arah pemenuhan kebutuhan tertentu atau kebutuhan sistem(George, n.d.). Disini dapat dilihat sebuah sistem antara satu elemen sangat berkaitan dan menyatu, jika ada masalah di satu elemen akan berpengaruh ke elemen yang lain. Struktural fungsional memandang sekolah sebagai sistem dimana didalamnya terdiri dari sub system yang saling berkaitan(Fernandes, 2017).

\section{Kesimpulan}

Berdasarkan hasil penelitian penulis tentang analisis penerapan RPP dalam pembelajaran studi kasus SMAN 3 Painan dan SMAN 2 Bayang), dapat diambil keismpulannya sebagai berikut:

1. Guru sosiologi di SMAN 2 Bayang dan SMAN 3 Painan sudah menerapkan RPP berdasarkan kurikulum 2013 namun belum optimal.

2. Didalam penerapan RPP dalam pembelajaran ada beberapa kendala yaitu kalau dilihat dari SMAN 2 Bayang terkendala karena sarana dan prasarana dan di SMAN 3 Painan terkendala dengan waktu yang sangat terbatas sehingga menjadi penghambat proses pembelajaran, tapi karakter peserta didik sangat mendukung dalam pembelajaran.

3. Jika dilihat dari teori AGIL, hubungan antara peserta didik, guru, dan kepala sekolah berjalan dengan baik, karena di dalam teori AGIL setiap elemen juga mengatur hubungan antar elemen yang ada dalam sistem atau struktur sehingga tercapai apa yang menjadi tujuan dalam struktur itu. 


\section{Daftar Pustaka}

1, Setyawanto, A., 2. H.S, S., \& Basuki, I. A. (2017). RENCANA PELAKSANAAN PEMBELAJARAN (RPP) GURU BAHASA INDONESIA TINGKAT SMP DI KOTA $M A L A N G$.

Abrory, M., \& Kartowagiran, B. (2014). EVALUASI IMPLEMENTASI KURIKULUM 2013 PADA PEMBELAJARAN MATEMATIKA SMP NEGERI KELAS VII DI KABUPATEN SLEMAN. Jurnal Evaluasi Pendidikan.

Arikunto. (2006). Metodologi Penelitian Sosial. Jakarta: Rineka Cipta.

Basrowi, \& Suwandi. (2008). Memahami Penelitian Kualitatife. jakarta: Rineka Cipta.

Ernawati. (n.d.). Analisis Kesulitan Guru Dalam Merancang Rencana Pelaksanaan Pembelajaran Mata Pelajaran Fisika Berdasarkan Kurikulum 2013 Di Kota Banda Aceh. 2017.

Fernandes, R. (2017). ADAPTASI SEKOLAH TERHADAP KEBIJAKAN PENDIDIKAN INKLUSIF. Jurnal Socius, 4.

George, R. (n.d.). Sosiologi Ilmu Pengetahuan Berparadigma Ganda. 2004: PT. Raja Grafindo Persada.

Hakim, L. (2010). Perencanaan Pembelajaran. Bandung: CV. Wacana Prima.

Ibrahim, I. (2016). Deskripsi Implementasi Kurikulum 2013 Dalam Proses Pembelajaran Matematika Di Sma Negeri 3 Maros Kabupaten Maros. Jurnal Daya Matematis, 3(3), 370. https://doi.org/10.26858/jds.v3i3.1704

j.1, maleong. (2004). Metodologi Penelitian Kualitatif. Bandung: Remaja Rosdakarya.

Mulflikh, U. (2017). PERAN GURU DALAM IMPLEMENTASI KURIKULUM 2013 PADAPEMBELAJARAN BIOLOGI DI SMPN 5 DAN SMPN 8 KOTA KEDIRI. SimkiTechsain.

Mulyasa, E. (2008). Kurikulum tingkat satuan pendidikan. Bandung: Remaja Rosdakarya.

Nadzir, M. (n.d.). perencanaan pembelajaran berbasis karakter. 2013.

Prambanan, S. M. A. N. I., Irenewaty, T., Hum, M., \& Sejarah, D. P. (2006). Kesulitan-Kesulitan Guru dalam Implementasi KTSP Mata Pelajaran Sejarah Sekolah Menengah Atas (SMA). 10(5).

s. suherman, W. (n.d.). Pengembangan Kurikulum Pendidikan Jasmani. yogyakarta: FIK UNY. sugiyono. (2005). Memahami Penelitian Kualitatif. Bandung: alfabeta.

Sylvia, I. (2012). UPAYA MENINGKATKAN KEMAMPUAN BERPIKIR KRITIS SISWA DALAM MATA PELAJARAN SEJARAH DENGAN PEMBELAJARAN SNOWBALL TRHOWING. Diakronika, XII(02), 163-182. https://doi.org/10.31227/osf.io/76cym

Terry Irenewaty, M. H. (2017). KESULITAN-KESULITAN GURU DALAM IMPLEMENTASI KTSP MATA PELAJARAN SEJARAH SEKOLAH MENENGAH ATAS (Penelitian di SMA NI Prambanan Klaten).

W. John, C. (2010). Research Design Pendekatan Metode Kualitatif, Kuantitatif dan Campuran. Yogyakarta: Pustaka Pelajar. 